www.jmscr.igmpublication.org

Index Copernicus Value: 79.54

ISSN (e)-2347-176x ISSN (p) 2455-0450

crossrefDOI: https://dx.doi.org/10.18535/jmscr/v7i1.179

\title{
A Clinico - Epidemiological Study of Acute Pyogenic Hand Infections - Retrospective Study of 50 Cases
}

\author{
Authors \\ Dr Jojo.V. Joseph ${ }^{1}$, Dr Mebin B Thomas ${ }^{2}$ \\ ${ }^{1}$ Consultant Surgical Oncologist, Caritas Cancer Institute, Kottayam \\ ${ }^{2}$ Junior Consultant Surgeon Caritas Hospital, Kottayam
}

\section{Introduction}

The importance of hand in human life is unimaginable. From an evolutionary aspect, our hands were relieved from duties of locomotion when we became bipeds. Many of our mental processes are developed by feeling and movements of hand.

The hand is composed of tough material together with a machinery of much refinement and tissues of great delicacy and specialization. The hand infiltrated and gutted by infections create several problems. After the tissues have sloughed out and the storm of infection is over, all the tissues contract and movable parts become bound with a cicatrix. Much of this complications can be prevented by early treatment of infection. As anywhere else, prevention is better than reconstruction of a frozen hand which requires specialized technique, place and person.

\section{Materials and Methods}

The aim of the study was to know the pattern of acute pyogenic hand infection in relation to age, sex, etiology, occupation, type of treatment and complication if any.

This retrospective study was done at caritas hospital, Kottayam Kerala from 1-1-2008 to 3-12-
2010 by reviewing the case files. The present study consists of 50 cases of acute pyogenic infection. All were treated either by conservative treatment or by incision and drainage.

\section{Observations}

The study of 50 cases of acute pyogenic hand infections were carried out. The results are analyzed in a tabulated form.

Table 1: Symptoms and Sign

\begin{tabular}{|l|c|c|}
\hline Symptoms and Sign & No. of cases & Percentage \\
\hline Pain & 50 & $100 \%$ \\
Swelling & 50 & $100 \%$ \\
Fever & 20 & $40 \%$ \\
H/O Trauma & 18 & $36 \%$ \\
Local rise of temp & 50 & $100 \%$ \\
Tenderness & 50 & $100 \%$ \\
Dorsal oedema & 31 & $62 \%$ \\
Pus discharge & 10 & $20 \%$ \\
Regional adenitis & 03 & $6 \%$ \\
Diabetes mellitus & 04 & $8 \%$ \\
Vascular insufficiency & 01 & $2 \%$ \\
\hline
\end{tabular}

Table 2: Duration of Symptoms

\begin{tabular}{|l|c|c|}
\hline $\begin{array}{l}\text { Duration of } \\
\text { Symptoms in days }\end{array}$ & No. of cases & Percentage \\
\hline 1-3 days & 30 & $60 \%$ \\
4-7 days & 18 & $36 \%$ \\
8-10 days & 02 & $04 \%$ \\
\hline
\end{tabular}


Table 3: Sex distribution

\begin{tabular}{|l|c|c|}
\hline Sex & No. of cases & Percentage \\
\hline Male & 28 & $66 \%$ \\
Female & 22 & $44 \%$ \\
\hline
\end{tabular}

Table 4: Age of the patients

\begin{tabular}{|l|c|c|}
\hline Age of the patients & No. of cases & Percentage \\
\hline $00-10$ & 08 & $16 \%$ \\
$11-20$ & 13 & $26 \%$ \\
$21-30$ & 10 & $20 \%$ \\
$31-40$ & 11 & $22 \%$ \\
$41-50$ & 03 & $06 \%$ \\
$51-60$ & 04 & $08 \%$ \\
$61-70$ & 01 & $02 \%$ \\
\hline
\end{tabular}

Table 5: Occupations of the patients

\begin{tabular}{|l|c|c|}
\hline $\begin{array}{l}\text { Occupations of the } \\
\text { patients }\end{array}$ & No. of cases & Percentage \\
\hline Manual laborer & 14 & $28 \%$ \\
Factory work & 12 & $24 \%$ \\
House work & 14 & $28 \%$ \\
Study & 08 & $16 \%$ \\
Pan business & 02 & $04 \%$ \\
\hline
\end{tabular}

Table 6: Site of infection

\begin{tabular}{|l|c|c|}
\hline Site of infection & No. of cases & Percentage \\
\hline Terminal pulp space & 10 & $20 \%$ \\
Middle volar space & 07 & $14 \%$ \\
Proximal volar space & 01 & $02 \%$ \\
Web space & 10 & $20 \%$ \\
Subcuticular & 01 & $02 \%$ \\
Thenar space & 04 & $08 \%$ \\
Deep palmar space & 02 & $04 \%$ \\
Radial bursa & 01 & $02 \%$ \\
A/C Paronychia & 01 & $02 \%$ \\
Dorsal subcutaneous & 02 & $04 \%$ \\
Cellulitis & 04 & $08 \%$ \\
combined & 07 & $14 \%$ \\
\hline
\end{tabular}

Table 7: Single/Combination Antibiotics

\begin{tabular}{|l|c|}
\hline Antibiotics & Number of patients \\
\hline Single & 06 \\
Combination & 44 \\
\hline
\end{tabular}

Table 8: Complications:

\begin{tabular}{|l|c|c|}
\hline Complications & $\begin{array}{c}\text { No. of } \\
\text { cases }\end{array}$ & Percentage \\
\hline No complications & 43 & $86 \%$ \\
Recurrence & 02 & $04 \%$ \\
Restriction of movement after 1 month & 03 & $06 \%$ \\
Osteomyelitis of terminal phalanx & 02 & $04 \%$ \\
\hline
\end{tabular}

\section{Discussion}

Hand infections and injury are getting more and more importance, because of the utmost importance of hand in all fine work. Maintenance of the normal movement and normal sensation is the basic aim behind changes in treatment methods of hand infection. The anatomy of hand plays a crucial role in planning the treatment of hand infections.

In Russia ${ }^{[19]}$ approximately $20 \%$ surgical outpatient report with disability of the hand with $25 \%$ of this are due to paronychia.

In the present study 50 cases of acute pyogenic infection of hand are included. The chronic infection and post-operative infection were excluded from the study.

All the patients under study presented with pain, swelling, local rise of temperature and tenderness. 31 patients had dorsal oedema explained by the fact that all lymphatics of hand transverse through the dorsum and dorsal skin is lax ${ }^{[3,11]}$.

Infection is introduced into hand compartments by direct injury and spread from other compartments. In this study the history of trauma was elicitable positively in only $36 \%$ of patients, probably because majority of the patients are manual laborer and housewives who are likely to neglect trivial trauma, which may be sufficient to cause an infection. Four patients had diabetes mellitus $2 \%$ had vascular in suffering due to raynods all of which are known risk factors ${ }^{[18]}$. The duration of symptoms was less than 4 days in 30 out of 50 patients. This is because the pus present under tension in the localized spaces of the hand produces severe early local symptoms ${ }^{[16]}$. In our study there is no remarkable difference in incidence of hand infections in males and females. This might be because, majority of females are laborer or house workers, predisposing them to trauma and infections. Regarding the age incidence $26 \%$ of patient were from 11-20 years and $20 \%$ of 21-30 years age group accommodating roughly $50 \%$ of patients under study.

Manual laborer, factory worker and house wives contribute the $75 \%$ of the patients proving trauma is an important etiological agent. Regarding the site of infection $36 \%$ of patient had finger infection and web space infection in $20 \%$ of patients. Some finding is noted by micheal R. ${ }^{[18]}$. 
Acute paronychia although noted by some as a very common infection of the hand ${ }^{[18,15,11]}$ was found only in $2 \%$ of the present series, as majority of these patients are treated with surgery in outpatient department, which this study has not included. According to micheal $\mathrm{R}^{[18]}$ the organisms are the descending order, staphylococcus aureus, methicillin, resistant staphylococcus, streptococci, gram negative bacteria and anaerobes which vary with site of infection and mode of injury.

Of the 50 patients under study 46 needed surgical intervention, 4 patients were treated conservatively (of cellulitis) with high doses of crystalline penicillin and cloxacillin). It is well known that conservative treatment will effect a cure only in a few cases and under specific condition $^{[4]}$.

Such success is unlikely if the patient presents after 48 hours of onset of infection because of certain anatomical peculiarity of hand and blood supply ${ }^{[10,3]}$.

Recurrence in two patients were due to inadequate drainage at the time of primary operation, 3 patients had restriction of movement at the end of 1-month follow-up. They were subjected to active physiotherapy by the specialist, and $95 \%$ of mobility was regained.

\section{Summary and Conclusion}

This study involve 50 cases of acute pyogenic hand infections admitted caritas hospital from January 2008 to December 2010.

1) The incidence of hand infection is higher in the age group 11-30 years.

2) The male population is affected more than the females.

3) The most common affected area is fingers, followed by web spaces. Deep space infections are comparatively rare.

4) The commonest microorganism responsible is staphylococcus aureus, followed by streptococcus.

5) Manual laborer and house wives are more affected.

\section{References}

1. Bingham, D.I.C: Acute infections of the hand surg. Clin. North Am. 40, 12851298, 1960.

2. Boffard K.D.: The hand 466-499 in Decker Le Mc Gregor's synopsis of surgical anatomy $12^{\text {th }} \mathrm{ED}$.

3. Lancet 1951, Jan.pp. 196-199.

4. Burton R.I. Hand 2061-2100 in Schwartz S.I/

5. Stoner, E.H., spencer F.C., principles of surgery $4^{\text {th }} \mathrm{ED}$.

6. Certer, S.J. Burman, S.O, MerSheimer, W.L. Treatment of digital tenosynovitis by irrigation which $\mathrm{H}_{2} \mathrm{O}_{2}$ and Antibiotic Ann. Surg. 163: 645-650,1966.

7. Eaton, R.C. Butch P.D. Antibiotic guidelines foe hand infections surg. Gyn. Obst. 130: 119-120.

8. Gorden I.: Expectant treatment of pyogenic infections of the hand with special reference to infection of flexor aspect of the fingers Br.J.sur.38:331,1950.

9. Kanaval A.B., Infections of the hand a guide to surgical treatment of acute and chronic suppurative processes in the fingers, hand and forearm, $7^{\text {th }} \mathrm{ED}$.

10. Naviser, R.J. infections 771-790 in green D.P. operative hand surgery newyork.

11. Rains A.J.H., Ritchie bailey and Love's short practice of surgery $19^{\text {th }} \mathrm{Ed}$. London ELBS, 1986.

12. Ramamurthy S. Anesthesis page 25-51 in green D.P. ED. operative hand surgery newyork.

13. Green D.P. principles pp. 1-24 in Green D.P operative hand surgery newyork.

14. Hooper G. : operations on the hand and fingers 131-153 in Rintaul R.F.ED Farquchansons text of operative surgery $7^{\text {th }}$ ED. London. Churchil Livingston.

15. G.M. Rayan et al,. microbiologic flora of human fingernails, Vol. 12 A No 4, july 1987, pp 604-606. 
16. L.C. Binghanm, M.B. Acute infections of the hand pp. 1284-1291, SCNA 1960.

17. Joan Sneddon, treatment of infections of the hand pp. 786-790, practitioner, 1979.

18. Micheal R.H. Hand infections, orthopedic clin,. North Am. Pp 171-185, Vol. 23, jan. 1992.

19. Orthopedic clinic of North Am. 6, 1063, to $1103,1975$.

20. The Journal of Hand Surgery Volume 39, Issue 8, August 2014, Pages 1628-1635 